\title{
Economic losses associated with Peste des petits ruminants in Turkana County Kenya
}

\author{
Simon M Kihu ${ }^{1,2^{*}}$, George C Gitao', Lily C Bebora', Njenga M John', Gidraph G Wairire ${ }^{3}$, Ndichu Maingi ${ }^{1}$ \\ and Raphael G Wahome ${ }^{1}$
}

\begin{abstract}
Peste des petits ruminants is a major economic disease affecting the pastoral herders in Kenya, with outbreaks in Turkana County having devastating effects on the Turkana livelihoods. Turkana County is a region associated with natural and manmade disasters, poor infrastructure and insecurity. There is limited essential data on livestock diseases and economic analysis. This study has attempted to estimate the direct economic loses occasioned by outbreaks of Peste des petits ruminants (PPR) based on perceived loss of benefits experienced by the Turkana people. Parameters for the analytical model were derived from secondary data, informal interviews and focused group discussions using participatory epidemiology methods. Results shows that losses due to PPR were estimated at US\$ 19.1 million and mortality of small stock due to PPR constituted the greatest economic loss valued at US\$ 16.8 million being 88\% of the total losses. Other losses due to lost milk and weight loss constitute approximately $12 \%$ of the total losses. PPR has serious economic impacts on pastoral livelihoods, and previous estimation of PPR losses in Kenya was grossly undervalued. This study strengthens the basis for developing a system for the economic assessment of livestock diseases in areas with scanty data based on parameters derived from participatory epidemiology approaches for use in the mathematical model.
\end{abstract}

Keywords: Peste des petits ruminants; Economic losses; Participatory epidemiology; Turkana

\section{Background}

Kenya's small ruminant herd stands at 29.5 million sheep and goats, with Turkana County small ruminant herd accounting for $32.2 \%$ of small ruminants in the country, with a population of 9.5 million head (KNBS 2010). The Turkana pastoralists in Kenya rely heavily on small stock as sources of income and for socio-cultural reasons. Small ruminants are an important means to rebuild their herds after environmental and political shocks and thus are a major component of pastoral coping mechanism (Elsawalhy et al. 2010; FAO 2013).

The outbreaks of Peste des petits ruminants (PPR) disease in 2007 in Kenya increased the risk to exposure of the small ruminant herds in Kenya to the disease (Kihu et al. 2012a). PPR is a contagious viral disease primarily affecting goats and sheep and creates epidemics that can cause mortality rates as high as $90 \%$ in immunologically

\footnotetext{
* Correspondence: simon.kihu@vetworks-ea.org

${ }^{1}$ Faculty of Veterinary Medicine, University of Nairobi, P.O. Box 29053-00625, Uthiru, Kenya

${ }^{2}$ Vetworks Eastern Africa, P.O. Box 10431-00200, Nairobi, Kenya

Full list of author information is available at the end of the article
}

naive sheep and goat populations, resulting in significant negative socio-economic impacts (Munir et al. 2013). PPR is a threat to small ruminant production and is ranked by pastoral communities among the top 10 diseases of small ruminants (Diallo 2006).

The economic losses of PPR outbreaks in Kenya during 2006 and 2007 outbreaks were generally estimated to have been over US\$ 15 million (Nyamweya et al. 2009). This study aims to provide estimates of direct economic losses to Turkana pastoralists during the subsequent PPR outbreaks in 2010 and demonstrate the negative economic impact of PPR.

\section{Study area}

The study was carried out in September 2011. The study area comprised six north-western administrative Divisions (Loima, Orropoi, Kakuma, Lokichogio, Kaaling and Kibish) of Turkana County, characterized by arid and semi-arid lands. Generally, the County experiences both temporal and spatial rainfall variability (Schilling et al. 2012). The small ruminant population is $9,512,012$

\section{实}


with $3,517,151$ sheep and 5,994,861 goats and constitutes $75.5 \%$ of livestock in Turkana County (KNBS 2010), the rest being cattle and camels.

\section{Methods Study design}

The sampling unit was a communal village herd (adakar) selected purposively and distributed across the six administrative Divisions of the study area. An adakar was defined as a cluster of often-related Turkana households with their herds coming together to pursue similar activities such as search for pasture, water and security, under a trusted leader (Bett et al. 2009). The six administrative Divisions are divided into Location units totaling 20. In each Location, three village herds were purposively selected for focused group discussions and/or informal interview. A total of 60 village herding groups were interviewed.

\section{Data collection}

Data collection adapted participatory epidemiological (PE) appraisal techniques for gathering of disease epidemiological and socio-economic data as described by Jost et al. (2010) and Catley et al. (2012). The data was gathered from the key informants through informal interviews and from village herders through focused group discussions, guided by checklists of open-ended questions that were pre-tested and adjusted prior to the start of the study.

Model parameters determined through informal interviews were as follows: small stock reproduction parameters, milk production levels and the value of milk. The value of milk was converted from Kenya shillings to US dollars. This information was collected from 30 livestock and 10 women milk traders selected purposively across the study area. Milk production and losses were estimated as described by Barasa et al. (2008), by asking the milking person to show her milking container and mark the level of milk produced by healthy goat and sheep. Water was filled to the marked level shown and then measured by a calibrated container. The milking women were then asked to show and mark the level of milk produced by goat and sheep which were sick with PPR. Water was again filled in the container to level of production of the sick animal and measured with a calibrated container.

The parameters on value of the animals were estimated from secondary data where the value of sheep and goats was considered in US\$ per tropical livestock unit (TLU) at US\$ 150 (Anteneh et al. 1988; Mude et al. 2010). One TLU was defined as being equivalent to one cow with a body weight of $250 \mathrm{~kg}$ while sheep and goats were defined as 0.125 TLU (McCabe 2004; Maass et al. 2012).

Model parameters determined through focused group discussions by proportional piling method were the following: relative incidence and mortality due to PPR, herd structures by age groups and proportion of males, females, pregnant and lactating animals. Respondents provided names of four age groups applied to goats and sheep. Age categories in sheep were as follows: newborn lambs (imethek) up to the age of 2 months, lambs in the age group between 3 and 5 months (nanyang), sheep in middle age group (amethek nakale) of 6 to 24 months while the adult sheep (amethek naapolon) were aged above 24 months. Age categories in goats were newborn kids up to 2 months (ikale), kids between 3 and 5 months (namenaoei), goats in middle age group (akale) aged between 6 to 24 months while the adult (akine) more than 24 months. Respondents divided a pile of 100 seeds among the four age groups of each species, to determine the proportionate age structure in each group.

Estimation of the proportions of mature females and males in the breeding herds was carried out by further subdividing the piles representing akale and akine age groups in goats and amethek nakale and amethek naapolon age groups of sheep to show relative proportions of males and females. To estimate the proportion of pregnant goats and sheep in a herd, respondents were asked to further sub-divide the piles of seeds representing the females in akale and akine age groups in goats and amethek nakale and amethek naapolon age groups of sheep, to show the relative proportions of pregnant and non-pregnant animals. Lactating goats and sheep were estimated to be equal to the proportion of young kids (ikale) for goats and young lambs (imethek), the assumption being each kid and lamb had one mother.

The incidence and mortality of PPR (called lomoo in the Turkana language) was determined relative to other five sheep and goat diseases and a category of 'other diseases' considered important by the Turkana. These five diseases of sheep were sheep pox (etune), anaplasmosis (lonyang), bottle jaw (loborbolio), anthrax (lookot) and foot and mouth (lojaa). Similarly for the goats, five diseases evaluated alongside PPR (lomoo) were caprine pleura-pneumonia (loukoi), thin goat syndrome (loutogonyen), diarrhoea (naosin), bottle jaw (loborbolio) and babesiosis (emany). Using a pile of 100 seeds to depict an age group, the respondents were asked to divide the seeds into two piles to show the pattern of sick goats and healthy goats during the previous one year (2010). The pile of seeds representing sick goats was then subdivided by the respondents to show the pattern of goats having each of the diseases listed above plus the 'other diseases' category. Each pile of seeds representing a disease category was then further sub-divided to show the pattern of goats dying and surviving for each disease category. This process was repeated for the sheep.

\section{Estimation of direct economic losses due to PPR}

Estimations of direct economic losses due to PPR mortality and morbidity in sheep and goats were calculated 
with the formulae derived from Bennett and Kitching (2000), Kivaria (2006), Singh and Prasad (2008) and Barasa et al. (2008) as expressed below, using the variables in Table 1.

Total direct loss $\left(T^{\mathrm{L}}\right)$ for the model herd is derived from mortality losses due to PPR $(L)$, milk losses associated with PPR $(M)$, body weight losses associated with PPR $(W)$ and opportunity cost of managing surviving animals $(O)$ as depicted by the formula:

$$
T^{\mathrm{L}}=L+M+W+O
$$

The participatory methodologies used in estimating the variables in this analytical model assumed a model herd of 100 sheep and 100 goats; therefore, the results were further extrapolated to cover actual field population of Turkana County as described by Barasa et al.
(2008). Thus, the model herd costs are converted to field herd model cost by the formula:

$$
T^{\mathrm{L}}=(L+M+W+O) \times(N / 100)
$$

where $N$ is the total population of sheep and goats in Turkana County.

The model was subjected to sensitivity analysis on selected input variables. Sensitivity analysis for the model was carried out by adjusting upwards by 5\%, 10\% and $20 \%$ the disease parameter of mortality and morbidity together, costing of milk, meat and live animal and delayed inter-kidding/lambing period.

\section{Mortality losses due to PPR}

Mortality losses were due to small stock dying of PPR, as well as the kids and lambs lost due to dying pregnant does and ewes.

\begin{tabular}{|c|c|}
\hline Parameter description & Methodology for estimation of parameter \\
\hline \multicolumn{2}{|l|}{ Herd age structure } \\
\hline$G^{y \ldots a}=$ proportion (\%) of sheep/goats in age group young to adult & $\begin{array}{l}\text { Proportional piling (PP) of sheep and goat herds by age group } \\
(n=27)\end{array}$ \\
\hline \multicolumn{2}{|l|}{ Losses due to mortality } \\
\hline$H^{y \ldots a}=$ PPR mortality (\%) of sheep/goats in age group young to adult & PP sheep $(n=43) /$ goat $(n=44)$ mortality by disease \\
\hline$H^{a}=$ mortality $(\%)$ of pregnant female & Mortality in adult sheep and goats \\
\hline $\begin{array}{l}C^{y \ldots a}=\text { value expressed in US\$/TLU } \mathrm{kg} \text { for sheep/goats in age group young } \\
\text { to adult }\end{array}$ & Value of sheep or goat in TLU $\left(C^{m e *} W^{y \ldots a}\right)$ \\
\hline \multicolumn{2}{|l|}{ Losses from reduced milk production } \\
\hline$S^{m \ldots . . f}=$ proportion (\%) of male and female sheep/goats in the herds & PP sheep $(n=6) /$ goat $(n=6)$ \\
\hline$L^{f}=$ proportion (\%) of lactating sheep/goats & Derivative of PP from $G^{y}$ \\
\hline$P^{f}=$ proportion $(\%)$ of pregnant sheep/goat & Derivative of PP sheep $(n=6) /$ goat $(n=6)$ \\
\hline$\mu^{\mu \cdots a}=$ prevalence (\%) of PPR in sheep/goats in age group young to adult & PP for disease prevalence \\
\hline $\mathrm{P}^{\mathrm{af}}=$ prevalence $(\%)$ of PPR in lactating sheep/goats & PP for disease prevalence $l^{\text {af }}$ equals $l^{\mathrm{a}}$ in adults \\
\hline$V^{\prime}=$ volume of milk loss (litres) per day per PPR case & Key informant interviews \\
\hline$T^{r}=$ duration (days) of reduced milk production per acute PPR case & Course of disease as described by Bundza et al. (1988) \\
\hline$V^{A}=$ daily volume (litres) of milk produced per healthy sheep/goat & Key informant interviews and literature (Njanja 1991) \\
\hline$T^{\prime}=$ lactation period (days) & Literature (Njanja 1991; Marete 2011) \\
\hline$C^{m}=$ sale value of milk (US\$/I) & Key informant interview with milk sellers \\
\hline$C^{m e}=T L U$ value expressed in US\$/unit weight of TLU & $\begin{array}{l}\text { TLU }=250 \mathrm{~kg} \text {; cost of TLU is US } \$ 150 . \text { Value of TLU/kg is US } \$ 0.6 \\
\text { (ILCA 1988; Mude et al. 2010) }\end{array}$ \\
\hline \multicolumn{2}{|l|}{ Losses due to weight losses } \\
\hline$W^{\prime}=$ proportion (\%) of body weight loss & Key informant interviews \\
\hline$W^{a \cdots y}=$ average body weight $(\mathrm{kg})$ of sheep/goat in age group young to adult & Key informant interviews with livestock officials and keepers \\
\hline$K=$ inter-kidding/lambing interval in days & Key informant interviews and literature (Njanja 1991) \\
\hline$B=$ birth weight $(\mathrm{kg})$ of $\mathrm{kid} / \mathrm{lamb}$ & Literature (Njanja 1991) \\
\hline$N=$ sheep/goat population in study area in Turkana County & KNBS 2010 Kenya population and livestock census data \\
\hline$Q=$ delay in conception in months due to disease & Key informant interviews and livestock keepers \\
\hline
\end{tabular}

Table 1 Summary of parameters and methodology for estimating losses due to PPR in Turkana pastoral herds 
Losses due to PPR mortality $\left(L^{\mathrm{d}}\right)$ were worked out as the product of the proportion of the sheep/goats in age groups young to adult (imethek to amethek in sheep and ikale to akine in goats) denoted as $\left(G^{\mathrm{a} \ldots \mathrm{y}}\right)$; PPR mortality in sheep/goats in age groups young to adult $\left(H^{\mathrm{y} \ldots \mathrm{a}}\right)$ and the TLU value of sheep/goats for each age group young to adult $\left(C^{\mathrm{y} \ldots \mathrm{a}}\right)$. The value of $\left(C^{\mathrm{y} \ldots \mathrm{a}}\right)$ is a product of the value of a TLU per $\mathrm{kg}\left(C^{\mathrm{me}}\right)$ and weight of each age group young to adult $\left(W^{\text {a...y }}\right)$. Based on insurance data and other literature, a TLU is valued at US\$150, and since a TLU is equivalent to $250 \mathrm{~kg}$, therefore a $\mathrm{kg}$ of TLU for sheep and goats is valued at an average of US\$ 0.6:

$$
L^{\mathrm{d}}=G^{\mathrm{y} \ldots \mathrm{a}} \times H^{\mathrm{y} \ldots \mathrm{a}} \times C^{\mathrm{y} \ldots \mathrm{a}}
$$

Losses from expected kids and lambs from pregnant doe/ewe dying of PPR $\left(L^{y}\right)$ was derived as a product of the proportion of pregnant sheep/goats $\left(P^{\mathrm{f}}\right)$, PPR mortality in sheep/goats in age group adult $\left(H^{\mathrm{a}}\right)$ and the TLU value in US\$ of sheep/goats for age group young $\left(C^{y}\right)$ :

$$
L^{\mathrm{y}}=P^{\mathrm{f}} \times H^{\mathrm{a}} \times C^{\mathrm{y}}
$$

Total mortality losses $(L)$ :

$$
L=L^{\mathrm{d}}+L^{\mathrm{y}}
$$

\section{Milk losses due to PPR}

Milk losses occasioned by PPR were from reduced milk yield from recovering PPR cases of lactating dams, as well as long-term losses due to increased inter-kidding/ lambing intervals.

Direct losses due to reductions in milk yield in convalescing cases of PPR within the lactating does/ewes $\left(M^{\mathrm{r}}\right)$ were calculated as a product of the proportion of lactating sheep/goat $\left(L^{\mathrm{f}}\right)$ multiplied by the difference of prevalence of PPR in lactating sheep/goats $\left(I^{\text {af }}\right)$ and mortality of lactating sheep and goats $\left(H^{\mathrm{a}}\right)$, volume of milk loss (litres) per day per PPR case $\left(V^{d}\right)$, duration (days) of reduced milk production per acute PPR case $\left(T^{\mathrm{r}}\right)$ and sale value of milk (US\$/litre) $\left(C^{\mathrm{m}}\right)$. Key informants indicated that milk loss $\left(V^{\mathrm{d}}\right)$ due to PPR disease was drastic and estimated at $60 \%$ in sheep and 50\% in goats. Only kids and lambs would be left suckling, yet milk production in some cases would not be enough, resulting in malnutrition and death in newborns. Duration and course of PPR disease as described by Bundza et al. (1988) informed the estimated duration of reduced milk production $\left(T^{\mathrm{r}}\right)$ :

$$
M^{\mathrm{r}}=L^{\mathrm{f}} \times\left(I^{\mathrm{af}}-H^{\mathrm{a}}\right) \times V^{\mathrm{l}} \times T^{\mathrm{r}} \times C^{\mathrm{m}}
$$

Milk losses due to increased inter-kidding/lambing period $\left(M^{\mathrm{y}}\right)$ was calculated as the reduction in proportion of lactating does/ewes in any year, being a product of sum of proportions of lactating $\left(L^{\mathrm{f}}\right)$ and pregnant does/ewes $\left(P^{\mathrm{f}}\right)$, recovering animals (difference of prevalence of PPR in lactating sheep/goats $\left(I^{\text {af }}\right)$ and mortality of lactating sheep and goats $\left(H^{\mathrm{a}}\right)$ ), lost kiddings/lambings, volume of milk production per sheep/goat $\left(V^{\mathrm{a}}\right)$, lactation period of sheep/goat and cost of milk per litre $\left(T^{\mathrm{l}}\right)$. The problem of non-conception caused by PPR increases the inter-kidding period and thus lower number of animals that would be in milk at any given time. A recovering sheep/goat lost a season equivalent to 5.5 months delay to the next conception:

$$
\begin{aligned}
M^{\mathrm{y}}= & \left(L^{\mathrm{f}}+P^{\mathrm{f}}\right) \times\left(I^{\mathrm{af}}-H^{\mathrm{a}}\right) \times(12 / K-12 /(K+Q)) V^{\mathrm{a}} \\
& \times T^{\mathrm{l}} \times C^{\mathrm{m}}
\end{aligned}
$$

Total milk losses $(M)$ :

$$
M=M^{\mathrm{r}}+M^{\mathrm{y}}
$$

\section{Body weight losses}

The surviving and convalescing sheep and goats lost weight and market value due to PPR disease. The body weight losses due to increased inter-kidding were estimated by calculating the lost kiddings and lambings.

The surviving convalescing sheep/goats lost weight and market value due to PPR disease. Direct losses due to body weight losses $\left(W^{\mathrm{d}}\right)$ were estimated as a product of the proportion of sheep/goats in all age groups $\left(G^{y \ldots a}\right)$, the proportion surviving the disease (difference of prevalence of PPR in all age groups of sheep/goats $\left(I^{\ldots \ldots y}\right)$ and mortality in all age groups of sheep and goats $\left.\left(H^{\mathrm{a}}\right)\right)$, multiplied by estimated proportion of weight loss per animal, estimated weight of sheep/goats in various age groups and cost of TLU per kilogram in US\$:

$$
W^{\mathrm{d}}=G^{\mathrm{y} \ldots \mathrm{a}} \times\left(I^{\mathrm{y} \ldots \mathrm{a}}-H^{\mathrm{y} \ldots \mathrm{a}}\right) \times W^{\mathrm{l}} \times W^{\mathrm{y} \ldots \mathrm{a}} \times C^{\mathrm{me}}
$$

Body weight losses due to increased inter-kidding $\left(W^{y}\right)$ was estimated a product of reduced proportion of lactating does/ewes in any year being a product of sum of proportions of lactating $\left(L^{\mathrm{f}}\right)$ and pregnant does/ewes $\left(P^{\mathrm{f}}\right)$, recovering animals (difference of prevalence of PPR in lactating sheep/goats $\left(I^{\mathrm{af}}\right)$ and mortality of lactating sheep and goats $\left(H^{\mathrm{a}}\right)$ ), the lost kidding and lambing due to PPR disease, birth weight of kids and lambs $(B)$ and TLU value per unit weight of in US\$ $\left(C^{\mathrm{me}}\right)$ :

$$
\begin{aligned}
W^{\mathrm{y}}= & \left(L^{\mathrm{f}}+P^{\mathrm{f}}\right) \times\left(I^{\mathrm{af}}-H^{\mathrm{a}}\right) \times(12 / K-12 /(K+Q)) \\
& \times B \times C^{\mathrm{me}}
\end{aligned}
$$

Total weight losses:

$$
W=W^{\mathrm{d}}+W^{\mathrm{y}}
$$




\section{Opportunity cost}

The use of conventional veterinary medicine in rural Turkana County is rare. Most herdsmen will gather herbs to treats ailments on their small stock. Veterinary medicines are expensive, and most herders access them through relief handouts from local development agencies. However, at times, herders buy affordable veterinary medicines or other concoctions of medical capsules and tablets of human medicine and apply them on sick small stock. In light of this, it was assumed that the Turkana people will put efforts into caring for the PPR surviving small stock at cost equivalent to $2.5 \%$ sale value of sheep and goats. Thus, opportunity cost will be a product of the proportion of sheep/goats in all age groups $\left(G^{\mathrm{y} \ldots \mathrm{a}}\right)$, the proportion surviving the disease (difference of prevalence of PPR in all age groups of sheep/goats $\left(I^{\mathrm{a} \ldots \mathrm{y}}\right)$ and mortality in all age groups of sheep and goats $\left.\left(H^{\mathrm{a}}\right)\right)$ and 0.025 of the value of $\left(C^{\mathrm{y} \ldots \mathrm{a}}\right)$ being a product of the value of a TLU per $\mathrm{kg}\left(C^{\mathrm{me}}\right)$ and weight of each age group young to adult $\left(W^{\text {a...y }}\right)$ :

$$
O^{\mathrm{c}}=G^{\mathrm{y} \ldots \mathrm{a}} \times\left(I^{\mathrm{y} \ldots \mathrm{a}}-H^{\mathrm{y} \ldots \mathrm{a}}\right) \times\left(.025^{*} C^{\mathrm{y} \ldots \mathrm{a}}\right)
$$

\section{Data management and statistical analysis}

Both qualitative and semi-quantitative data were collected in the study. The qualitative data were presented without being subjected to formal statistical analyses. The quantitative data was entered and cleaned in Microsoft Excel (Microsoft Corp., Redmond, WA, USA). It was then exported to SPSS (2008) statistical software version 17.0 (IBM Corp., Armonk, NY, USA) for analysis using non-parametric statistical tests. Analyses were undertaken using descriptive statistical procedures and data summarized using medians to determine central tendency, while dispersion was expressed by 10th and 90th percentile estimation. The data to be used in the spreadsheet model was maintained in Microsoft Excel and model outputs computed following the insertion of the formulae.

\section{Results}

Small stock production and PPR disease parameters

Small stock productivity parameters in the Turkana pastoral production system were estimated through participatory epidemiology and secondary data (Tables 2 and 3). The age structure results shows that middle age sheep and adult sheep constitute the first two largest age groups in the herd with a population proportion of $24 \%$ and $37.7 \%$, respectively (Table 2).

A similar pattern is established in goats, with middle age goat population proportion being $21 \%$ and adult goats 38\% (Table 2) of goat herds. The breeding female sheep and goats constitute $37.7 \%$ and $36.1 \%$ respective for each species' herd population (Table 3). In both sheep and goats, the relative mortality due to PPR was highest in adults, being $20 \%$ and $16.66 \%$, respectively (Table 2).

\section{Direct economic losses associated with PPR disease in Turkana County}

The losses due to mortality of sheep and goats due to PPR were around US\$ 16.8 million, accounting for $88 \%$ of the total losses. The proportion of sheep mortality losses was US\$ 6.2 million while goats contributed US\$ 10.6 million in mortality losses. Milk losses due to PPR were estimated

Table 2 PPR disease parameters, age structure, weight and sale value of sheep and goats in Turkana County 2010

\begin{tabular}{|c|c|c|c|c|}
\hline \multirow[b]{2}{*}{ Parameter for the sheep } & \multicolumn{4}{|c|}{ Median (10th and 90th percentiles) } \\
\hline & $\begin{array}{l}\text { New born lambs } \\
\text { (imethek) }\end{array}$ & $\begin{array}{l}\text { Older lambs } \\
\text { (nanyang) }\end{array}$ & $\begin{array}{l}\text { Middle age sheep } \\
\text { (amethek nakale) }\end{array}$ & $\begin{array}{l}\text { Adult sheep } \\
\text { (amethek naapolon) }\end{array}$ \\
\hline$G^{y \ldots a}=$ age structure sheep median proportion (\%) & $15.84(8.27,22.40)$ & $20.79(13.83,28.34)$ & $24.00(17.83,34.63)$ & $37.37(28.01,50.20)$ \\
\hline$W^{y \ldots a}=$ average live weight per age group & 2.5 & 4.5 & 10 & 30 \\
\hline$C^{y \ldots a}=T L U$ value for each age group sheep (US\$) & 1.5 & 2.7 & 6.0 & 18.0 \\
\hline$H^{y \cdots a}=$ relative mortality due to PPR in the age groups & $17.00(5.40,31.00)$ & $17.00(6.45,34.90)$ & $16.00(7.33,37.15)$ & $20.00(7.80,34.90)$ \\
\hline$P^{y \ldots a}=$ relative incidence of PPR in the age groups & $20.00(7.00,38.00)$ & $20.00(10.00,40.36)$ & $19.00(9.87,40.03)$ & $25.00(11.40,40.78)$ \\
\hline $\mathrm{If}^{\mathrm{af}}=$ relative incidence of PPR in the lactating groups & & & & $25.00(11.40,40.78)$ \\
\hline Parameters for the goats & $\begin{array}{l}\text { Newborn kids } \\
\text { (ikale) }\end{array}$ & $\begin{array}{l}\text { Older kids } \\
\text { (namenaoei) }\end{array}$ & $\begin{array}{l}\text { Middle age goats } \\
\text { (akale) }\end{array}$ & $\begin{array}{l}\text { Adult goats } \\
\text { (akine) }\end{array}$ \\
\hline$G^{\mathrm{y} \ldots \mathrm{a}}=$ age structure goat median proportion (\%) & $18.75(12.00,24.44)$ & $20.2(14.77,29.96)$ & $21(17.46,27.06)$ & $38(25.24,53.20)$ \\
\hline$W^{y \ldots a}=$ average live weight per age group & 2.5 & 5 & 12.5 & 35 \\
\hline$C^{y \ldots a}=T L U$ value for each age group goat (US\$) & 1.5 & 3.0 & 7.5 & 21.0 \\
\hline$H^{y \ldots a}=$ relative mortality due to PPR in the age groups & $14.21(6.05,28.56)$ & $17.00(5.50,25.5)$ & $16.32(6.50,26.5)$ & $16.66(7.45,35.00)$ \\
\hline$P \cdots a$ a relative incidence of PPR in the age groups & $17.79(8.50,32.13)$ & $20.47(8.43,31.00)$ & $20.00(9.50,30.00)$ & $20.88(10.41,36.00)$ \\
\hline $\mathrm{If}^{\mathrm{af}}=$ relative incidence of PPR in the lactating groups & & & & $20.88(10.41,36.00)$ \\
\hline
\end{tabular}


Table 3 Small stock production parameters in Turkana County in $\mathbf{2 0 1 0}$

\begin{tabular}{|c|c|c|}
\hline Parameter & Sheep & Goats \\
\hline$B=$ birth weight (kilograms) & 1.9 & 2.1 \\
\hline$K=$ normal inter-kidding/lambing interval in days & 252 & 344 \\
\hline $\begin{array}{l}Q=\text { inter-kidding/lambing interval in sick animals } \\
\text { in days }\end{array}$ & 417 & 509 \\
\hline$V^{A}=$ normal volume milk production in litres & 0.49 & 0.73 \\
\hline$V^{\prime}=$ volume of milk loss per PPR case & 0.3 & 0.4 \\
\hline$T^{\prime}=$ lactation period in days & 120 & 120 \\
\hline $\begin{array}{l}T^{\top}=\text { duration days of reduced milk production per } \\
\text { surving PPR case }\end{array}$ & 20 & 20 \\
\hline$C^{m}=$ sale value of milk (US\$/litre) & 0.58 & 0.58 \\
\hline$C^{\text {me }}=$ value of TLU (US\$/kilogram) & 0.6 & 0.6 \\
\hline $\begin{array}{l}W^{\prime}=\text { proportion (\%) of weight loss in surviving } \\
\text { PPR case }\end{array}$ & 30 & 30 \\
\hline$P^{f}=$ proportion (\%) of pregnant animals & 20 & 15 \\
\hline$L^{f}=$ proportion (\%) of lactating animals & 15.84 & 18.75 \\
\hline$S^{m \ldots f}=$ proportion (\%) of breeding females & 37.67 & 36.12 \\
\hline$N=$ sheep and goat population in Turkana & $3,517,151$ & $5,994,861$ \\
\hline
\end{tabular}

at US\$ 0.94 million for both sheep and goats accounting for $5 \%$ of the total losses. Sheep proportion of milk losses was US\$ 0.26 million while milk losses in goats were US\$ 0.68 million. Weight losses attributed to PPR disease caused an estimated loss of US\$ 1.3 million in both sheep and goats. Major weight losses were recorded in goats at US\$ 0.78 million while sheep weight losses were US\$ 0.47 million. Opportunity cost of local treatments of PPR in Turkana accounted for US\$ 99,296. Total direct production losses in sheep were US\$ 6.9 million accounting for $36.4 \%$ of the total losses. The production losses in goat herds were US\$ 12.1 million accounting for $63.6 \%$ of the total direct economic losses. The total estimated direct economic losses associated with PPR for sheep and goats in Turkana County for the year 2010 were estimated to be US\$ 19.1 million (Table 4).

Sensitivity analysis for the model herd was carried out by adjusting upwards mortality and morbidity together, costing of milk, meat and live animal and delayed interkidding/lambing period by $5 \%, 10 \%$ and $20 \%$. The result of the sensitivity analysis model showed a similar increase in proportion of the total cost for all the parameters altered, in Table 5.

\section{Discussion}

PPR disease has entrenched itself and became endemic in Turkana County, thus causing cyclic outbreaks that perpetually result in continuous economic losses to the herders. The losses due to PPR disease that impact on small stock benefits were mainly due to mortality, milk and weight losses. Since the production losses due to
Table 4 Calculated production losses associated with PPR in sheep and goats

\begin{tabular}{|c|c|c|}
\hline & \multicolumn{2}{|c|}{ Losses in US dollars } \\
\hline & Sheep & Goat \\
\hline \multicolumn{3}{|l|}{ Mortality } \\
\hline$L^{d}=\left(G^{y \ldots a} \times H^{y \ldots a} \times C^{y \ldots a}\right) \times(N / 100)$ & $5,972,889$ & $10,368,074$ \\
\hline$L^{y}=\left(P^{f} \times H^{a} \times C^{y}\right) \times(N / 100)$ & 211,029 & 224,717 \\
\hline$L=L^{d}+L^{y}$ & $6,183,919$ & $10,592,791$ \\
\hline \multicolumn{3}{|l|}{ Milk losses } \\
\hline$M^{r}=\left(L^{f} \times\left(l^{f}-H^{a}\right) \times V^{l} \times T^{r} \times C^{m}\right) \times(N / 100)$ & 22,619 & 69,000 \\
\hline $\begin{array}{l}M^{y}=\left(\left(L^{f}+P^{f}\right) \times\left({ }^{a}-H^{a}\right) \times(365 / K-365 /\right. \\
\left.(K+Q)) V^{a} \times T^{\top} \times C^{m}\right) \times(N / 100)\end{array}$ & 236,188 & 608,367 \\
\hline$M=M^{d}+M^{r}+M^{y}$ & 258,807 & 677,367 \\
\hline \multicolumn{3}{|l|}{ Losses due to weight losses } \\
\hline $\begin{array}{l}W^{d}=\left(G^{y \ldots a} \times\left(P^{y \ldots a}-H^{y \cdots a}\right) \times W^{\prime} \times\right. \\
\left.W^{y \cdots a} \times C^{m e}\right) \times(N / 100)\end{array}$ & 428,312 & 744,959 \\
\hline $\begin{array}{l}W^{y}=\left(\left(L^{f}+P^{f}\right) \times\left(l^{\mathrm{l}}-H^{\mathrm{af}}\right) \times(365 / K-365 /\right. \\
\left.K+Q) \times B \times C^{\mathrm{e}}\right) \times(N / 100)\end{array}$ & 41,179 & 37,003 \\
\hline$W=W^{d}+W^{y}$ & 469,491 & 781,962 \\
\hline \multicolumn{3}{|l|}{ Opportunity cost } \\
\hline $\begin{array}{l}O^{c}=\left(G^{y \ldots a} \times\left(P^{y \ldots a}-H^{y \ldots a}\right) \times\left(.025^{*} C^{Y \ldots a}\right)\right) \times \\
(N / 100)\end{array}$ & 35,479 & 63,817 \\
\hline$O=O^{c}$ & 35,479 & 63,817 \\
\hline \multicolumn{3}{|l|}{$\begin{array}{l}\text { Total direct economic losses for field herd } \\
\text { in Turkana }\end{array}$} \\
\hline$T^{L}=L+M+W+O$ & $6,947,696$ & $12,115,938$ \\
\hline Combined total loss & $19,063,633$ & \\
\hline
\end{tabular}

PPR were conceived to be different for different age groups of small stock, herd structures for goats and sheep were established through focused group discussions with Turkana herders, shown in Table 2. Our findings compared well with small stock age structure of a study herd in Turkana reported by Njanja (1991), where adult sheep were $51.5 \%$, immature $26.4 \%$ and preweaned at $22.1 \%$ whereas the adult goats were $51.8 \%$, immature $21.1 \%$ and pre-weaned $27.2 \%$. The proportion of breeding females in sheep and goats (Table 3) was also found to be comparable with Njanja (1991), who

Table 5 Sensitivity analysis for direct economic losses due to PPR for the model herd

\begin{tabular}{llll}
\hline & \multicolumn{3}{l}{$\begin{array}{l}\text { Increment on total cost (US\$) \% in parenthesis } \\
\text { as the effect of increasing parameter by }\end{array}$} \\
\cline { 2 - 4 } $\begin{array}{l}\text { Disease and } \\
\text { market parameter }\end{array}$ & $\mathbf{5 \%}$ & $\mathbf{1 0 \%}$ & $\mathbf{2 0 \%}$ \\
\hline $\begin{array}{l}\text { Mortality and } \\
\text { morbidity }\end{array}$ & $+78.54(4.8 \%)$ & $+157.09(9.091 \%)$ & $+314.18(16.66 \%)$ \\
$\begin{array}{l}\text { Milk, meat and } \\
\text { live animal costs }\end{array}$ & $+78.54(4.8 \%)$ & $+157.09(9.091 \%)$ & $+314.18(16.66 \%)$ \\
Inter-kidding/ & $+0.83(0.05 \%)$ & $+1.63(0.1 \%)$ & $+3.15(0.2 \%)$ \\
lambing interval & & & \\
\hline
\end{tabular}


reported $36.5 \%$ and $40.6 \%$ for sheep and goats, respectively. In our study, mortalities due to diseases were $70 \%$ and $74.2 \%$ in sheep and goats as established from participatory epidemiology. Other studies in Turkana have reported lower percentages, for example, McCabe (2004) reported $1 \%$ to $50 \%$ losses in small stock due to diseases, de Vries (2002) reported 41\% mortalities in small stock due to various causes, including disease, while Wienpahl (1985) reported $62 \%$ to $68 \%$ losses due to drought and diseases.

Meat, milk and live small stock were the three prioritized benefits of small stock rearing. Though milk production in small East African goats and sheep is low and heavily dependent on prevalence of rains, milk plays an important role in food security of Turkana pastoralists, particularly where herds are large. Women and elderly folks will be seen with tin or plastic containers milking the few millilitres from the small stock in the kraals every morning before they are released for grazing. Herd boys and girls will milk the nursing small stock and harvest blood from rams and bucks for their day's food intake. In our study, it was established that the milk production per day in sheep and goats was 0.49 and 0.73 litres, respectively. We were aware that the average daily milk production as derived from herders' assessments (Table 3) was higher than the figures quoted in the literature. For example, the findings reported by Njanja (1991), McCabe (2004) and Bruins et al. (2003) ranged from 0.1 to 0.55 litre per day for goat does and 0.9 to 0.25 litre per day for ewes. Our further discussion with respondent groups established that the volume measurement they provided were reflections of the actual milk production in their milking sheep and goats during the wet season.

Small stock are also considered as 'mobile banks', easily mobilized into income for paying household expenditures, particularly in lean times. In addition to this economic role, sheep and goats have significant sociocultural roles. They are used as gifts or emblems for traditional rituals and religious purposes. Weak and sickly animals are not used for traditional and religious purposes, particularly if they are emaciated. Anecdotes are told of how herders rushed to settle their social obligations when they got to know their herd were likely infected with PPR in 2006 (Kihu et al. 2012b). The derived benefits of small stock are lost when herds get infected with PPR. However, only direct losses occasioned by mortality, milk losses and weight were considered in this study. In establishing these losses due to mortality and weight losses, we converted the lost animals into TLUs which were then valued based on the cost of a TLU at US\$ 150 for pastoral livestock in East Africa (Anteneh et al. 1988; Mude et al. 2010). The value of milk was based on local market rates converted into US\$. Other economic losses occasioned by failed socio-cultural obligations and networks following the loss of animals are difficult to quantify (Barasa et al. 2008).

This study has attempted to capture and quantify the losses of direct benefits of small stock rearing as incurred from PPR infection and as perceived by the Turkana people. The study has established that the direct economic losses due to PPR in Turkana for the year 2010 were in the tune of US\$ 19 million. Previous estimates of economic losses due to PPR reported by the Government of Kenya were US\$ 15 million (Nyamweya et al. 2009), which could have been considerably underestimated.

\section{Conclusion}

PPR remains a major economic disease affecting the Turkana pastoralists. As the herders lose their small stock due to PPR, they begin a perilous journey of joining the categories of the poor population, resulting in disruption of the cultural system and economy. The disease has the potential of destroying livelihoods and reducing most herders to destitution. This constitutes an economic disaster whose process is poorly understood due to lack of data from these areas. At the County and national level, data on livestock productivity in pastoral semi-arid and arid areas is scarce and rarely updated. Turkana County, being an extreme rural pastoral area with insecurity, poor infrastructure and communication, has provided very little incentive for data collection on livestock productivity, save for the few research studies mainly on conflict. This present study strengthens the basis for developing a system for the economic assessment of livestock diseases in areas with scanty data, using parameters derived from participatory epidemiology approaches for use in the mathematical model.

\section{Competing interests}

The authors declare that they have no competing interest.

\section{Authors' contributions}

SMK, LCB, GGW, NM and CGG collected the data, created the electronic database, cleaned and processed the data for analysis. SMK, GGW, NMJ, RGW and LCB conceived and performed the data analysis. SMK drafted the manuscript assisted by NM, RGW, CGG, LCB, NMJ and GGW. CGG, LCB, NMJ, GGW, NM and RGW raised the funding for the study and assisted in its coordination. All authors helped with the interpretation of the results and read and approved the final manuscript.

\section{Author details}

${ }^{1}$ Faculty of Veterinary Medicine, University of Nairobi, P.O. Box 29053-00625, Uthiru, Kenya. ${ }^{2}$ Vetworks Eastern Africa, P.O. Box 10431-00200, Nairobi, Kenya. ${ }^{3}$ Faculty of Arts, University of Nairobi, P.O. Box 30197-00100, Nairobi, Kenya.

Received: 8 September 2014 Accepted: 2 April 2015

Published online: 13 April 2015

\section{References}

Anteneh A, S Sanford, and B Anteneh. 1988. Policy, finance and technology in livestock development in sub-Sahara Africa. Some critical issues. Addis Ababa, Ethiopia: International Livestock Centre for Africa (ILCA) Bulletin Number 31 July 1988. 
Barasa MA, D Catley, H Machuchu, E Laqua, D Puot, D Tap Kot, and D Ikiror. 2008. Foot-and-mouth disease vaccination in South Sudan: benefit-cost analysis and livelihoods impact. Transboundary and Emerging Diseases 55(2008): 339-351.

Bennett RM, and AS Kitching. 2000. Estimating the costs associated with livestock diseases - A study of 30 diseases of livestock in Great Britain open access content International Symposia on Veterinary Epidemiology and Economics proceedings, ISVEE 9: Proceedings of the 9th Symposium of the International Society for Veterinary Epidemiology and Economics, 72. Breckenridge, Colorado, USA: Economics \& livestock production session.

Bett B, C Jost, R Allport, and J Mariner. 2009. Using participatory epidemiological techniques to estimate the relative incidence and impact on livelihoods of livestock diseases amongst nomadic pastoralists in Turkana South District, Kenya. Preventive Veterinary Medicine 90(3-4): 194-203.

Bruins HJ, JJ Akong'a, MMEM Rutten, and GM Kressel. 2003. Drought planning and rainwater harvesting for arid-zone pastoralists: the Turkana and Maasai (Kenya) and the Negev Bedouin (Israel). NIRP Research for Policy Series Part 17: Royal Tropical Institute. The Netherlands: KIT Publishers Amsterdam.

Bundza A, A Afshar, TW Dukes, DJ Mayers, GC Dulac, and SAWE Becker. 1988. Experimental peste des petits ruminants (goat plague) in goats and sheep. Canadian Journal of Veterinary Research 52: 46-52.

Catley A, RG Alders, and JLN Wood. 2012. Participatory epidemiology: approaches, methods, experiences. The Veterinary Journal 191: 151-160.

de-Vries DH. 2002. Livestock redistribution dynamics in nomadic pastoralist herd demography: A case study among the Ngisonyoka Turkana of south Turkana, Kenya. Masters thesis. Chapel Hill: Department of Anthropology, University of North Carolina

Diallo A. 2006. Control of Peste des petits ruminants and poverty alleviation. Journal of Veterinary Medicine 53: 11-13.

Elsawalhy A, JC Mariner, D Chibeu, H Wamwayi, S Wakhusama, W Olaho-Mukani, and P Toye. 2010. Pan African strategy for the progressive control of Peste des petits ruminants (Pan African PPR strategy). Bulletin of Animal Health and Production in Africa 58(3): 185-193.

FAO. 2013. Supporting livelihoods and building resilience through peste des petits ruminants (PPR) and small ruminant diseases control. Animal Production and Health Position Paper. Rome. E-ISBN 978-92-5-107582-1 (PDF). http:// www.fao.org/docrep/017/aq236e/aq236e.pdf. Accessed 27 Jan 2014.

Jost CC, S Nzietchueng, S Kihu, B Bett, G Njogu, ES Swai, and JC Mariner. 2010. Epidemiological assessment of the Rift Valley fever outbreak in Kenya and Tanzania in 2006 and 2007. Am J Trop Med Hyg 83(2 Suppl):65-72. doi:10.4269/ajtmh.2010.09-0290.

Kihu, SM, LM Njagi, GN Njogu, JN Kamande, and CG Gitao. 2012a. Peste des petits ruminants in Kenya; pastoralist knowledge of the disease in goats in Samburu and Baringo Counties. Research Opinion in Animal and Veterinary Science 2(11): 544-553.

Kihu SM, GC Gitao, LC Bebora, MJ Njenga, GG Wairire, N Maingi, and RG Wahome. 2012b. Participatory risk assessment of Peste des petit ruminants: Factor analysis of small ruminants pastoral management practices in Turkana district, Kenya. Research Opinions in Animal and Veterinary Sciences 2(9): 503-510.

Kivaria FM. 2006. Estimated direct economic costs associated with tick-borne diseases on cattle in Tanzania. Tropical Animal Health and Production 38:291-299. doi:10.1007/s11250-006-4181-2.

KNBS. 2010. 2009 Kenya population and housing census. Volume 1 A. Population distribution by administrative units. Nairobi, Kenya: Kenya National Bureau of Statistics, August 2010.

Maass BL, DK Musale, WL Chiuri, A Gassner, and M Peters. 2012. Challenges and opportunities for smallholder livestock production in post-conflict South Kivu eastern DR Congo. Tropical Animal Health and Production 44: 1221-1232. doi:10.1007/s11250-011-0061-5.

Marete A. 2011 Sheep. http://www.infonet-biovision.org. Accessed 22 Jan 2014.

McCabe JT. 2004. Cattle bring us to our enemies: Turkana ecology, politics, and raiding in a disequilibrium system. Ann Arbor: University of Michigan Press.

Mude A, S Chantarat, CB Barrett, M Carter, M Ikegami, and J McPeak. 2010. Insuring against drought-related livestock mortality: Piloting index based livestock insurance in Northern Kenya. http://dyson.cornell.edu/faculty_sites/cbb2/files/papers/ MudeetalPilotingIBLlinNorthernKenyaJune2010_2_.pdf. Accessed 12 Nov 2014.

Munir M, S Zohari, and M Berg. 2013. Molecular biology and pathogenesis of peste des petits ruminants virus. 2013:151. ISSN 2211-7504, ISBN 978-3-64231450-6, doi:10.1007978-3-64231451-3, Springer Briefs in Animal Sciences; http://www.springer.com/978-3-642-31450-6.

Njanja JC. 1991. Livestock ecology in Central Turkana. United Nations Educational Scientific and Cultural Organization (UNESCO). TREMU Technical Report No. E - 1.
Nyamweya M, T Otunga, G Regassa, and S Maloo. 2009. Technical brief of peste des petits ruminants virus. Nairobi, Kenya: ELMT Livestock Services Technical Working Group.

Schilling J, FEO Opiyo, and J Scheffran. 2012. Raiding pastoral livelihoods: Motives and effects of violent conflict in north-western Kenya. Pastoralism: Research, Policy and Practice 2:25. http://www.pastoralismjournal.com/content/2/1/25. Accessed 18 June 2013.

Singh B, and S Prasad. 2008. Modelling of economic losses due to some important diseases in goats in India. Agricultural Economics Research Review 21: 297-302.

Wienpahl J. 1985. Turkana herds under environmental stress. Nomadic Peoples 17:59-88.

\section{Submit your manuscript to a SpringerOpen ${ }^{\odot}$ journal and benefit from:}

- Convenient online submission

- Rigorous peer review

- Immediate publication on acceptance

- Open access: articles freely available online

- High visibility within the field

- Retaining the copyright to your article

Submit your next manuscript at $>$ springeropen.com 